\title{
17ß-Hydroxysteroid Dehydrogenase Type 2: Chromosomal Assignment and Progestin Regulation of Gene Expression in Human Endometrium
}

\author{
M. Linette Casey, ${ }^{\star}$ Paul C. MacDonald, ${ }^{\star}$ and Stefan Andersson ${ }^{\ddagger}$ \\ *The Cecil H. and Ida Green Center for Reproductive Biology Sciences, and the Departments of Biochemistry and \\ Obstetrics-Gynecology, The University of Texas Southwestern Medical Center, Dallas, Texas 75235-9051; \\ and the ${ }^{\ddagger}$ Department of Biochemistry, Merck Research Laboratories, Rahway, New Jersey 07065
}

\begin{abstract}
The cDNAs for two separate human 17ß-hydroxysteroid dehydrogenases (17 $\beta$-HSD) have been isolated and sequenced. The well-studied human placental cytosolic $17 \beta$ HSD (also referred to as estradiol dehydrogenase) preferentially catalyzes the reduction of estrone to estradiol-17 $\beta$ and the reduction of the $\mathrm{C}$-20-ketone of progesterone to $20 \alpha$ dihydroprogesterone. This isoform of the enzyme has been referred to as $17 \beta$-HSD type 1 and localized to chromosome 17. A second 17 $\beta$-HSD isoform (referred to as type 2 ) is localized in the endoplasmic reticulum of human trophoblast and is characterized by the preferential oxidation of the $\mathrm{C}$-17 $\beta$-hydroxyl group of $\mathrm{C}_{18^{-}}$and $\mathrm{C}_{19}$-steroids and the C-20 $\alpha$-hydroxyl group of $\mathbf{2 0 \alpha}$-dihydroprogesterone. In this study, we determined the chromosomal localization of human $17 \beta$-HSD type 2 , the expression of this gene in human endometrium, and the tissue distribution of the mRNA. We found that the human $17 \beta$-HSD type 2 gene is localized on chromosome 16, 16q24. 17 $\beta$-HSD type 2 mRNA ( $\sim 1.5 \mathrm{~kb})$ was identified in human endometrial tissues by Northern analysis of total RNA (10 $\mu \mathrm{g})$. The highest levels of 17 $\beta$ HSD type 2 mRNA were found in endometrial tissues obtained during the mid- to late secretory phase of the ovarian cycle (i.e., during the time of high plasma levels of progesterone). 17 $\beta$-HSD type 2 mRNA levels were much greater in glandular epithelium than in the stromal cells isolated from secretory phase endometrium. The levels of 17 $\beta$-HSD type 2 mRNA in secretory phase endometrium were approximately one-tenth that in villous trophoblast tissue from human placenta. We did not detect $17 \beta$-HSD type $1 \mathrm{mRNA}$ in endometrial tissue by Northern analysis of total ( $10 \mu \mathrm{g})$ RNA. These findings are consistent with the view that the progestinregulated $17 \beta$-HSD of the glandular epithelium of the human endometrium is primarily, if not exclusively, the product of the 17 $\beta$-HSD type 2 gene. 17 $\beta$-HSD type 2 mRNA
\end{abstract}

Address correspondence to M. Linette Casey, Ph.D., The Cecil H. and Ida Green Center for Reproductive Biology Sciences, The University of Texas Southwestern Medical Center, 5323 Harry Hines Boulevard, Dallas, TX 75235-9051.

Received for publication 29 April 1994 and in revised form 28 July 1994.

J. Clin. Invest.

(c) The American Society for Clinical Investigation, Inc. $0021-9738 / 94 / 11 / 2135 / 07 \quad \$ 2.00$

Volume 94, November 1994, 2135-2141 was present in human placenta, liver, and small intestine; much smaller amounts, barely detectable by Northern analysis of poly $(A)^{+}$RNA, were present in prostate, kidney, pancreas, and colon, but not in heart, brain, skeletal muscle, spleen, thymus, ovary, or testis. (J. Clin. Invest. 1994. 94:2135-2141.) Key words: endometrium • 17 $\beta$-hydroxysteroid dehydrogenase $\bullet$ progesterone $\bullet$ estradiol-17 $\beta$ - chromosome 16

\section{Introduction}

It is established that estradiol-17 $\beta$, and not estrone, is the principal estrogen secreted by the human placenta (see reference 1 ), ovary ( see reference 2), and testis (3). Also, testosterone (and not androstenedione) is secreted by the adult human testis ( 3 ), and progesterone (and not $20 \alpha$-dihydroprogesterone) is the primary $\mathbf{C}_{21}$-steroid secreted by human placenta (1) and corpus luteum (4). The adrenal cortex, and most tumors of the adrenal, secrete androstenedione (but not testosterone) and small amounts of progesterone but little or no $20 \alpha$-dihydroprogesterone $(5,6)$. Contrarily, many extraglandular tissues preferentially convert estradiol- $17 \beta$ to estrone, testosterone to androstenedione, and progesterone to $20 \alpha$-dihydroprogesterone ( 5 , $7-9)$. It is unlikely that this anatomical distribution of $17 \beta$ hydroxysteroid (17 $\beta$-HSD) ${ }^{1}$ and $20 \alpha$-hydroxysteroid oxidation/reduction activities, favoring C-17 and C-20 reduction in some tissues and oxidation in others can be accounted for by the redox potential of a given cell. Rather, it is much more likely that this difference in sex steroid hormone synthesis and metabolism is attributable to tissue-specific expression of isozymes that catalyze the $17 \beta$-oxidation-reduction of $\mathrm{C}_{19^{-}}$and $\mathrm{C}_{18}$-steroids and the $20 \alpha$-oxidation-reduction of progesterone, in a manner similar to that now recognized for the $3 \beta$-hydroxysteroid dehydrogenase family of enzymes (10). A number of investigators have deduced, therefore, that there must be multiple $17 \beta$-HSDs, some of which also are capable of C-20 $\alpha$-oxidoreduction.

In human placenta, the cytosolic isoform of $17 \beta$-HSD, most recently referred to as $17 \beta$-HSD type $1(11)$, is most efficient in the reduction of estrone to estradiol- $17 \beta$ and much less effective in $17 \beta$-oxidation-reduction of $\mathrm{C}_{19}$-steroids. A cDNA for this enzyme has been isolated and sequenced by several groups of investigators $(12-14)$. Thus, the placental cytosolic $17 \beta$ -

1. Abbreviation used in this paper: $17 \beta$-HSD, $17 \beta$-hydroxysteroid dehydrogenase. 
HSD enzyme (also referred to as estradiol-17 $\beta$ dehydrogenase) preferentially catalyzes the reduction of estrone to give the biologically potent estradiol-17 $\beta$ and the reduction of $16 \alpha$-hydroxyestrone to give estriol. Estradiol-17 $\beta$ and estriol are the principal estrogens secreted from the syncytiotrophoblast into the maternal circulation during human pregnancy (see reference 1). In addition, a microsomal $17 \beta$-HSD has been identified in human placenta; this membrane-bound enzyme preferentially catalyzes the oxidation of the $17 \beta$-hydroxyl group of estradiol$17 \beta$ and testosterone as well as the $20 \alpha$-hydroxyl group of $20 \alpha$ dihydroprogesterone (15). Recently, Andersson and associates (11) cloned the cDNA for this microsomal form of $17 \beta$-HSD and referred to this isozyme as $17 \beta$-HSD type 2 .

The most striking structural difference between the predicted amino acid sequences of $17 \beta$-HSD types 1 and 2 is an extended hydrophobic amino terminus of the microsomal $17 \beta$ HSD type 2 enzyme, which is believed to correspond to the transmembrane signal anchor. The amino acid sequence of the lumenal portion of $17 \beta$-HSD type 2 shares $23 \%$ homology and $45 \%$ similarity with $17 \beta$-HSD type 1 (11). The human $17 \beta$ HSD type 1 has been mapped by Winqvist and colleagues (16) to chromosome 17 (wherein a pseudogene is localized in tandem with the gene). Herein we report that human $17 \beta$-HSD type 2 gene is on chromosome 16, 16q24.

There has been considerable controversy concerning the particular type(s) of $17 \beta$-HSD in endometrium and other extraglandular tissues. This is an important issue from both the biochemical and physiological perspectives. Gurpide and colleagues $(17-22)$ were the first to show that progesterone and synthetic progestins act in vivo and in vitro to cause a striking increase in the enzymatic oxidation of estradiol-17 $\beta$ to estrone in human endometrium and in selected human endometrial carcinoma cells in culture. These findings have been confirmed by several other groups of investigators (23-25). This enzyme activity was localized particularly in the glandular epithelium of the endometrium $(23,26)$. From these findings, it has been reasoned that one action of progesterone as an antiestrogen in endometrial glands is effected by facilitating the oxidation of estradiol-17 $\beta$ (a potent estrogen) to the biologically weak or inactive estrone. Moreover, the progestin-induced increase in $17 \beta$-HSD activity should serve to preserve progesterone action in endometrium by favoring the $\mathrm{C}$-20-ketone configuration rather than the reduction of progesterone to inactive $20 \alpha$-dihydroprogesterone. Similar findings with respect to progestin stimulation of $17 \beta$-HSD activity have been described in studies of human breast cancer cells $(27,28)$. The identity of the $17 \beta$ HSD (s) in endometrium or breast, however, was not certain. In this investigation, we evaluated the levels of mRNAs for $17 \beta$-HSD types 1 and 2 in human endometrial tissue and in separated endometrial glandular epithelium and stromal cells in monolayer culture. By Northern analysis of total RNA $(10 \mu \mathrm{g})$ with cDNA probes for the coding regions, we found that $17 \beta$ HSD type 2 , but not type 1 , mRNA was present in high levels and that $17 \beta$-HSD type 2 mRNA levels increased strikingly with progesterone secretion in vivo. In addition, we surveyed other human adult tissues for $17 \beta$-HSD type 2 mRNA.

\section{Methods}

Endometrial and placental tissues. Endometrial tissues were obtained after hysterectomy, conducted for reasons other than endometrial disease, from the uteri of ovulatory women. Informed consent for the use of tissues was obtained in writing from each woman before the surgical procedure. The consent form and protocol used were approved by the Institutional Review Board of this university. The day of the endometrial cycle was estimated from the woman's menstrual history and by histological examination of the endometrium. In addition, the concentration of progesterone in plasma of the women from whom endometrial tissue was obtained was determined. From the plasma concentration of progesterone, we normalized the estimated day of the cycle for each endometrial sample to an idealized $28-\mathrm{d}$ interval.

Within $1 \mathrm{~h}$ of hysterectomy, endometrial tissues were frozen in liquid $\mathrm{N}_{2}$ (for isolation of RNA) or else placed in culture medium (for separation of glands and stroma) and transported to the laboratory. Endometrial glandular epithelium and stromal cells of some endometrial tissue samples were separated as described (29). Briefly, endometrial tissue was minced into small pieces $\left(\sim 1 \mathrm{~mm}^{3}\right)$, and the minced tissue was incubated at $37^{\circ} \mathrm{C}$ for $20-40 \mathrm{~min}$ in Hanks' balanced salt solution that contained Hepes ( $25 \mathrm{mM}$ ), penicillin $(200 \mathrm{U} / \mathrm{ml})$, streptomycin (200 $\mathrm{mg} / \mathrm{ml})$, collagenase $(1 \mathrm{mg} / \mathrm{ml} ; 134 \mathrm{U} / \mathrm{mg})$, and DNAse $(0.08$ $\mathrm{mg} / \mathrm{ml} ; 1,950 \mathrm{Kunitz}$ units $/ \mathrm{ml}$ ). The dispersed endometrial stromal cells were separated from endometrial glands by filtration through a wire sieve $(75 \mu \mathrm{m})$. The separated glandular epithelium and stromal cells (in the filtrate) were washed and pelleted by centrifugation ( $400 \mathrm{~g}, 10$ min). Villous trophoblast tissue was obtained from a placenta of a normal human pregnancy delivered at term.

Northern analyses. Total RNA was purified from endometrial tissues or separated cells by the method of Chirgwin et al. (30). The tissues or cells were homogenized in guanidinium isothiocyanate (4 M) and the homogenates were centrifuged at $238,000 \mathrm{~g}$ for $18 \mathrm{~h}$ at $25^{\circ} \mathrm{C}$ over $\mathrm{CsCl}(5.7 \mathrm{M})$. The total RNA was size fractionated by electrophoresis on formaldehyde-agarose (1\%) gels (5-10 $\mu \mathrm{g} /$ lane) and transferred electrophoretically to a nylon membrane. The RNA was cross-linked to the nylon membranes by ultraviolet irradiation. RNA from human tissues [ $2 \mu \mathrm{g}$ poly $(\mathrm{A})^{+} \mathrm{RNA} /$ lane] on a nylon membrane (Clontech Laboratories, Inc., Palo Alto, CA) also was probed for $17 \beta$-HSD type 2 . The membranes were prehybridized for $24 \mathrm{~h}$ at $42^{\circ} \mathrm{C}$ in prehybridization buffer comprised of formamide ( $50 \%$, by volume), $\mathrm{NaH}_{2} \mathrm{PO}_{4}(250 \mathrm{mM}$, $\mathrm{pH} 7.2), \mathrm{NaCl}(250 \mathrm{mM}), \mathrm{SDS}$ (7\%, wt/vol), and denatured sheared salmon sperm DNA $(100 \mu \mathrm{g} / \mathrm{ml})$. Hybridizations were conducted for $16 \mathrm{~h}$ at $42^{\circ} \mathrm{C}$ in the same buffer that contained $17 \beta$-HSD type 2 cDNA probe (11) or a $17 \beta$-HSD type $1 \mathrm{cDNA}(12)$ probe $\left(2 \times 10^{6} \mathrm{cpm} / \mathrm{ml}\right)$ radiolabeled with $\left[\alpha-{ }^{32} \mathrm{P}\right] \mathrm{dCTP}$ using random hexanucleotide primers and Klenow. The $17 \beta$-HSD type 1 cDNA was kindly provided to us by Dr. Michael Gast (Washington University, St. Louis, MO). After hybridization, the blots were washed with $2 \times$ SSC and SDS $(0.1 \%$, wt/ vol) for $15 \mathrm{~min}$ at room temperature, twice with $0.1 \times \mathrm{SSC}$ and SDS $(0.1 \%$, wt/vol ) for $20 \mathrm{~min}$ at room temperature, and two to four times with $0.1 \times S S C$ and SDS $(0.1 \%$, wt $/ \mathrm{vol})$ for $30 \mathrm{~min}$ at $55^{\circ} \mathrm{C}$. The membranes were blotted on filter paper, sealed in a plastic bag, and exposed to film with intensifying screens for autoradiography at $-80^{\circ} \mathrm{C}$. The presence of equal amounts of total endometrial tissue RNA in each lane was verified by visualization of $18 \mathrm{~S}$ and $28 \mathrm{~S}$ rRNA subunits or by analysis of $\beta$-actin using a specific cDNA purchased from Clontech Laboratories, Inc.

Genomic library screening and fluorescence in situ hybridization. A human genomic library in the Lambda Fix II vector was purchased from Stratagene (catalog no. 946205; Stratagene, La Jolla, CA). Screening in $50 \%$ formamide-containing buffers was conducted by use of standard procedures (31) with random hexanucleotide primed ${ }^{32} \mathrm{P}$-labeled probes derived from the full-length human $17 \beta$-HSD type 2 cDNA (11). The 13-kb DNA insert from the hybridization-positive bacteriophage lamda 49-24 was subcloned into pBluescript II (Stratagene) and analyzed by double-stranded DNA sequencing. The lambda 49-24 clone contained a segment identical to nucleotides $1-350$ in the $17 \beta$-HSD type 2 cDNA, flanked by unknown sequences. Fluorescence in situ hybridization (BIOS Laboratories, New Haven, CT) was performed using the method of Lichter et al. (32) with minor modifications. The plasmid was labeled with digoxigenin-11-dUTP by nick-translation, and the labeled probe was combined with sheared human DNA and hybrid- 


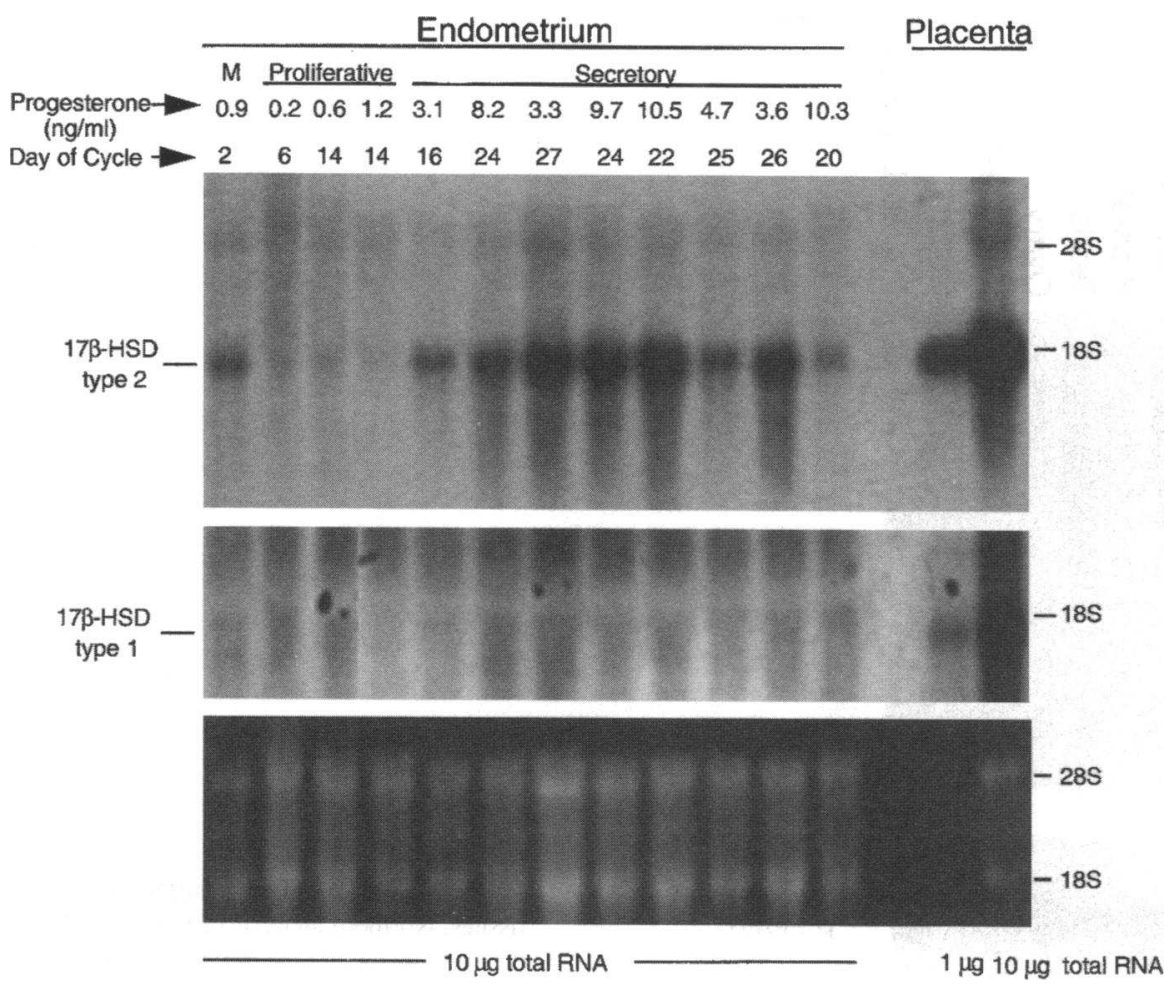

Figure 1. Northern analyses of $17 \beta$-HSDs mRNAs in human endometrial tissue. The levels of $17 \beta$-HSD type 2 mRNA (top) and $17 \beta$-HSD type 1 mRNA (middle) mRNA were evaluated by Northern analysis of total RNA (10 $\mu \mathrm{g} /$ lane); the ethidium-stained blot is presented in the bottom panel. Endometrial tissues were obtained from the menstrual $(M)$, proliferative, or secretory phases of the cycle. The day of the cycle is indicated as is the plasma level of progesterone on the day the tissue was obtained. For reference total RNA ( 1 and $10 \mu \mathrm{g}$ ) from villous placental tissue also is included on the blot. ized to normal human metaphase chromosomes in a solution containing formamide $(50 \%, \mathrm{vol} / \mathrm{vol}), 2 \times \mathrm{SSC}$, and dextran sulfate $(10 \%$, vol/ vol). Specific hybridization signal was detected with FITC-conjugated anti-digoxigenin antibodies and the chromosomes were then counterstained with propidium iodide.

\section{Results}

$17 \beta$-HSD type 2 mRNA was readily detected by Northern analysis of total RNA (10 $\mu \mathrm{g}$ ) prepared from human endometrium. The cDNA probe for $17 \beta$-HSD type 2 hybridized with a species of mRNA $\sim 1.5 \mathrm{~kb}$ in length. The level of $17 \beta$-HSD type 2 mRNA was greater in secretory than in proliferative endometrium (Fig. 1) and was highest during the mid to late secretory phase of the cycle, when plasma progesterone levels are maximum and progesterone action is greatest. The level of $17 \beta$-HSD type $2 \mathrm{mRNA}$ in mid-secretory endometrium was approximately one-tenth of that in placenta (Fig. 1). When this blot was probed for $17 \beta$-HSD type $1 \mathrm{mRNA}$, an mRNA species of $\sim 1.3 \mathrm{~kb}$ was detected in placental tissue but not in endometrial tissues.

$17 \beta$-HSD type $2 \mathrm{mRNA}$ was localized principally in the glandular epithelium of the endometrium (Fig. 2). In three different endometrial tissues obtained during the secretory phase, the level of $17 \beta$-HSD type 2 mRNA was much greater in the glands than in the stroma and much greater than that in either cell type of three endometrial tissue samples obtained during the proliferative phase of the cycle. A small amount of $17 \beta$-HSD type 2 mRNA was present in stroma of two of the secretory endometrial tissues. As it is not possible to separate completely the two cell types, we suspect that this may be accounted for by a small number of epithelial cells in the stromal preparation. Using cytokeratin as a marker of epithelial cells, we estimated the extent of epithelial cell contamination of the stromal cell preparation to vary from 2 to $17 \%$ (33).
$17 \beta$-HSD type 2 mRNA ( $\sim 1.5 \mathrm{~kb})$ also was detected in human placenta, liver, pancreas, kidney, and small intestine by - Northern analysis of poly $\left(\mathrm{A}^{+}\right)$RNA $(1 \mu \mathrm{g})$ (Fig. 3). In placenta, $\mathrm{a} \sim 1.3-\mathrm{kb}$ species of mRNA also was detected with the $17 \beta$-HSD type 2 cDNA probe. On longer exposure $(90 \mathrm{~h})$ of this blot of poly (A) ${ }^{+}$RNA, a faint signal, corresponding to a size of $\sim 1.5 \mathrm{~kb}$, was detected in colon and prostate. The level of $17 \beta$-HSD type 2 mRNA detected among these human tissues was greatest in placenta, liver, and small intestine, with the levels in kidney, pancreas, colon, and prostate being much lower. Also, on long exposure $(90 \mathrm{~h})$, there was a faint signal in with poly (A) ${ }^{+}$RNA from peripheral blood leukocytes, but the size of this mRNA appears to be slightly greater $(\sim 1.6 \mathrm{~kb})$

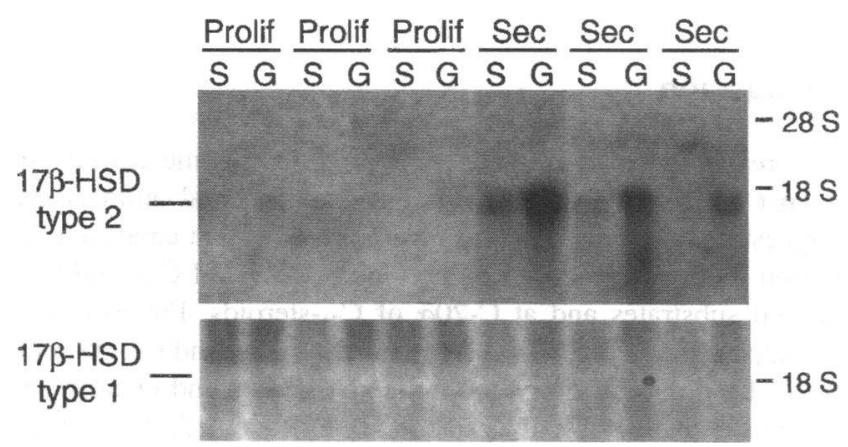

Figure 2. Northern analyses of $17 \beta$-HSD type 2 and type 1 mRNAs in separated glands and stroma isolated from human endometrial tissue. The stromal $(S)$ cells and glands $(G)$ in endometrial tissues obtained during the proliferative $(n=3)$ or secretory $(n=3)$ phase were separated and RNA was prepared. Total RNA ( $5 \mu \mathrm{g}$ RNA) was evaluated by Northern analyses for $17 \beta$-HSD type 2 (top) and $17 \beta$-HSD type 1 (bottom). 

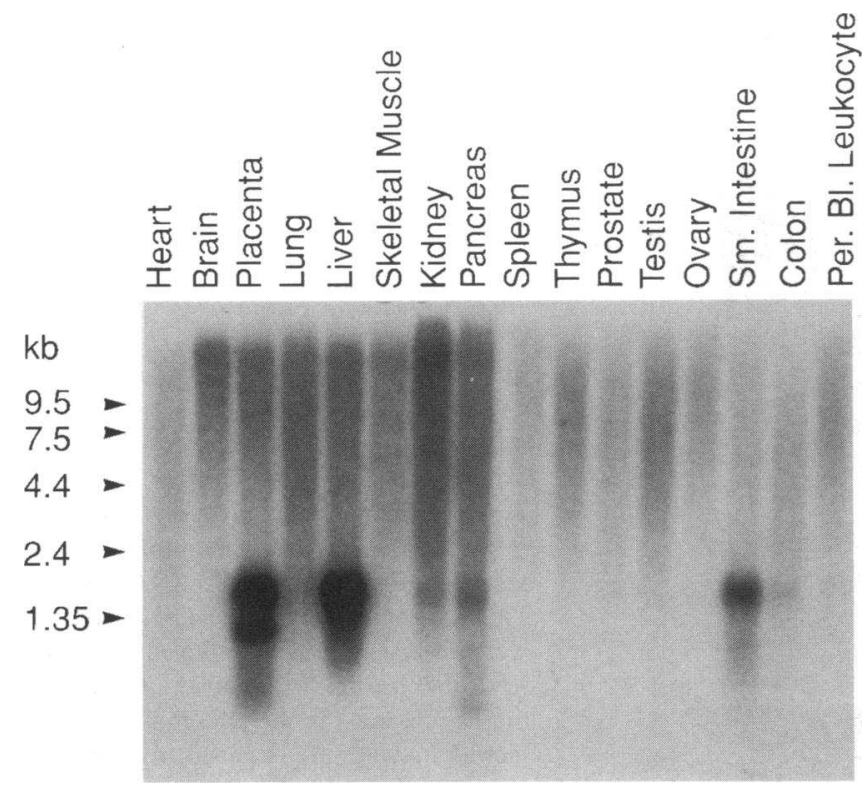

\section{- $17 \beta$-HSD Type 2}

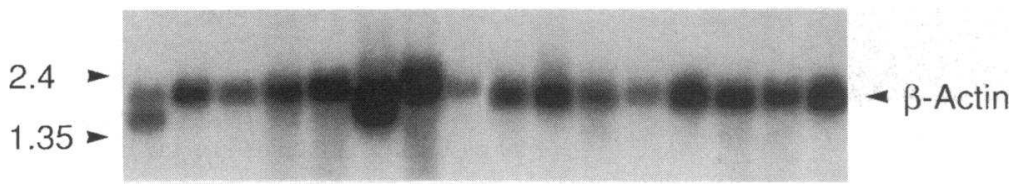

Figure 3. 17 $\beta$-HSD type 2 mRNA in human tissues. Northern analysis of poly $(\mathrm{A})^{+}$RNA ( $2 \mu \mathrm{g} /$ lane; membrane purchased from Clontech Laboratories, Inc.).

than that in endometrium, liver, and small intestine. Even with poly (A ) ${ }^{+}$RNA and long exposure $(90 \mathrm{~h})$, there was no evidence of $17 \beta$-HSD type 2 mRNA in heart, brain, skeletal muscle, spleen, thymus, or testis.

Using fluorescence in situ hybridization with human metaphase chromosomes, the $17 \beta$-HSD type 2 gene was localized to the distal long arm of chromosome 16 (Fig. 4). The identity of chromosome 16 was confirmed by cohybridization studies using the $17 \beta$-HSD type 2 probe and a chromosome 16 -specific centromere probe, D16Z2 (34) (Fig. 4). From measurements taken in 20 chromosome $16 \mathrm{~s}$, it was determined that the $17 \beta$ HSD type 2 gene is located $89 \%$ of the distance from the centromere to the telomere of $16 \mathrm{q}$. This area corresponds to $16 \mathrm{q} 24$. Specific signal was detected on chromosome 16 in 57 of 75 metaphase cells evaluated.

\section{Discussion}

The results of many studies of $17 \beta$-HSD enzyme activity in a host of tissues from humans and experimental animals are suggestive that there must be several proteins that catalyze oxidation-reduction reactions of steroids at $\mathrm{C}-17 \beta$ of $\mathrm{C}_{18^{-}}$and $\mathrm{C}_{19^{-}}$ steroid substrates and at $\mathrm{C}-20 \alpha$ of $\mathrm{C}_{21}$-steroids. For example, the apparent $K_{\mathrm{m}} \mathrm{s}$ of $17 \beta$-HSD(s) for $\mathrm{C}_{18^{-}}, \mathrm{C}_{19^{-}}$, and $\mathrm{C}_{21^{-}}$-steroids differ by ordefs of magnitude in some tissues and even in selected subcellular fractions of the same tissue $(15,35,36)$. In addition to steroid substrate specificity, the oxidative pathway of the reaction catalyzed by $17 \beta$-HSD is dominant in some tissues (in the absence of added co-factor [e.g., with intact cells or tissue slices]), whereas reduction is more prevalent in others (37-40). Furthermore, whereas the reduction pathway is important in the synthesis of the bioactive $\mathrm{C}_{18^{-}}$and $\mathrm{C}_{19}$-steroids, estradiol-17 $\beta$ and testosterone, respectively, the $\mathrm{C}-20 \alpha$ reduc- tion of progesterone serves, in the human at least, to inactivate this steroid hormone. Contrarily, the preferential oxidation of the $\mathrm{C}-17 \beta$-hydroxy group gives rise to biologically inactive estrone and androstenedione from estradiol-17 $\beta$ and testosterone, respectively; but, the oxidation of $20 \alpha$-dihydroprogesterone gives bioactive progesterone. These differences in steroid C-17 $\beta$ and C-20 $\alpha$ oxidation-reduction cannot be explained singularly by assuming that a given isozyme is localized in steroidogenic tissues and another isozyme is localized in extraglandular tissues. This obtains because the bioactive products of the reduction pathway, e.g., estradiol- $17 \beta$, and the oxidative pathway, e.g., progesterone, are preferentially secreted by the same steroidogenic cells in some tissues, e.g., the luteinized granulosa cells of the corpus luteum and the syncytiotrophoblast of the placenta (41). Similarly, we cannot deduce that extraglandular metabolism by the oxidative pathway results singularly in steroid hormone inactivation because the oxidation of $20 \alpha$-dihydroprogesterone gives rise to bioactive progesterone.

The findings of this study are indicative that $(a)$ human $17 \beta$-HSD type 2 is localized on chromosome $16,16 \mathrm{q} 24$ and (b) $17 \beta$-HSD type 2 is the progestin-responsive gene expressed in endometrial glandular epithelial cells. The levels of mRNA for this gene in endometrial glands are increased in vivo during the secretory phase of the cycle with increased progesterone secretion. By Northern analysis of total RNA, we could not detect transcripts for the $17 \beta$-HSD type 1 gene in either endometrial tissue or in separated endometrial cells by Northern analysis of total RNA. This finding is consistent with the finding of others that immunoreactive $17 \beta$-HSD is not demonstrable in endometrium using an antibody prepared against purified placental cytosolic $17 \beta$-HSD (42). Other investigators detected $17 \beta$-HSD type $1 \mathrm{mRNA}$ in low levels in endometrium when large amounts $(20 \mu \mathrm{g})$ of poly (A) ${ }^{+}$RNA (43) or RNase protection assays (44) were used. 

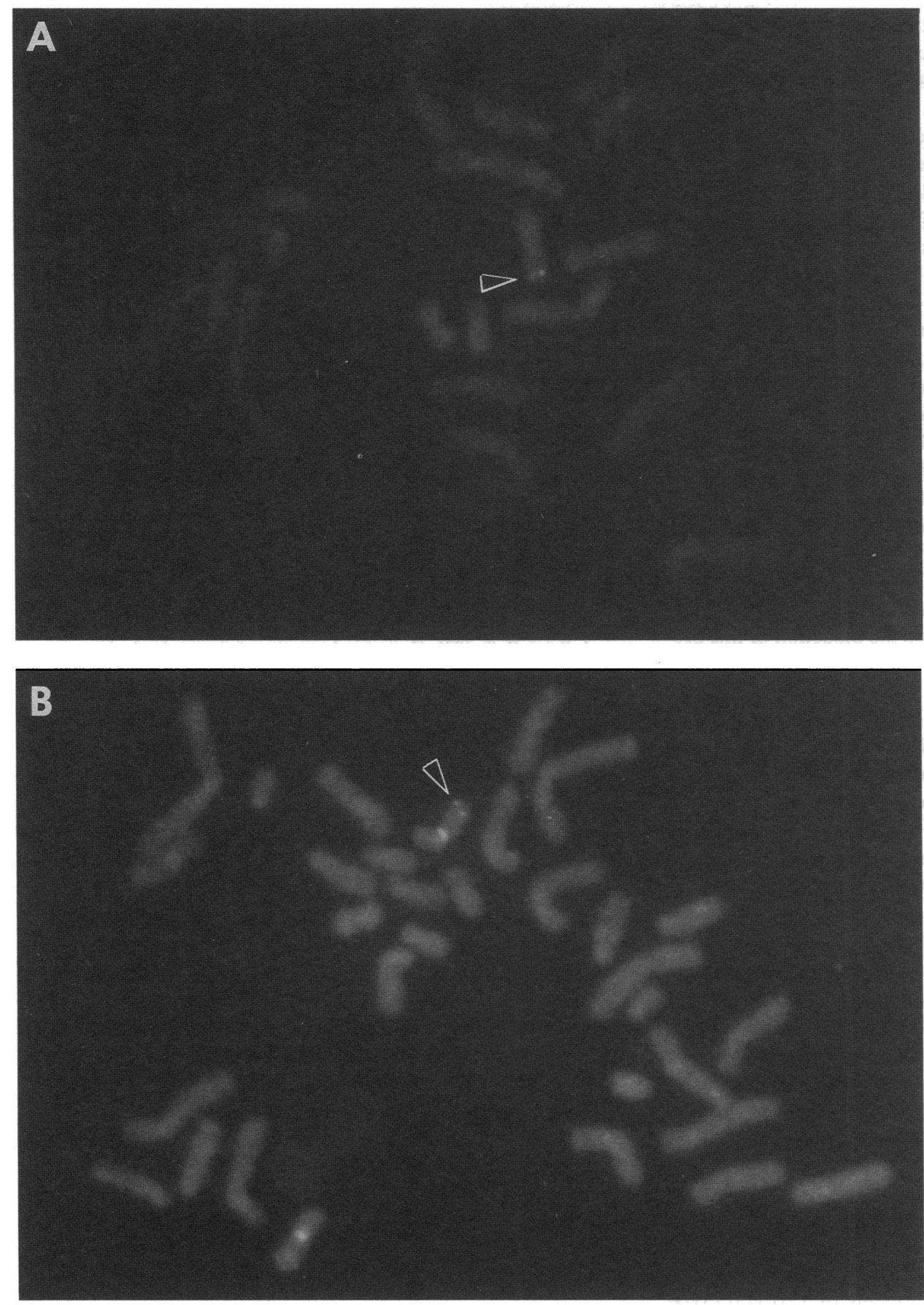

Figure 4. Fluorescence in situ hybridization of a genomic probe for $17 \beta$ HSD type 2 with human metaphase chromosomes. The $17 \beta$-HSD type 2 gene was localized to the distal long arm of chromosome 16 ( $A$ and $B$, arrows), which was identified using a chromosome 16-specific centromere probe, D16Z2 (34) (B).

As characterized by Andersson and colleagues (11), 17 $\beta$ HSD type 2 isozyme preferentially catalyzes the oxidation of estradiol-17 $\beta$ to estrone, presumably resulting in a tissue-specific decrease in estrogenic activity. This enzyme also catalyzes the oxidation of testosterone to androstenedione and $20 \alpha$-dihydroprogesterone to progesterone. These enzyme characteristics are consistent with the proposition that $17 \beta$-HSD type 2 functions in selected extraglandular tissues to diminish estrogen and androgen action but to preserve the action of progesterone. In the studies of Tseng and Gurpide (19), the preferential oxidation of $17 \beta$-hydroxy $\mathrm{C}_{19^{-}}$and $\mathrm{C}_{18}$-steroids and C-20 $\alpha$-hydroxy steroids was demonstrated in endometrial tissues. Moreover, this enzyme activity was localized in the glandular epithelium and not in the stroma and the specific activity of $17 \beta$-HSD was increased in vivo and in vitro by treatment with progestin $(17$, 19, 26). These findings, together with those of this investigation, are supportive of the conclusion that the progestin-stimulated $17 \beta$-HSD of the glandular epithelium of human endometrium is the type 2 isozyme. In addition, progestins act in human endometrium to increase estrone sulfotransferase activity and to decrease the synthesis of estrogen receptors (45-47). Collectively, these findings are suggestive that progestins act in a coordinated manner to attenuate estrogen action in endometrium, as suggested by Gurpide.

The human placenta is characterized by the secretion of very large amounts of estradiol-17 $\beta(10-15 \mathrm{mg} / 24 \mathrm{~h})$ and 
estriol (60-150 mg/24 h) but very little or no secretion of estrone into the maternal compartment (see reference 1). Similarly, the human placenta secretes phenomenal amounts of progesterone (200-600 mg/24 h) but very little $20 \alpha$-dihydroxyprogesterone $(37,48)$. These considerations, together with the fact that the human placenta uses plasma-borne $C_{19}$-steroids for estrogen formation $(49,50)$, give rise to a reasonable explanation for the actions of both $17 \beta$-HSD types 1 and 2 in trophoblast. The plasma-borne $\mathrm{C}_{19}$-steroids used for placental estrogen synthesis, dehydroepiandrosterone sulfate $(49,50)$ and $16 \alpha-$ dehydroepiandrosterone sulfate, are converted by placental sulfatase activity to the respective nonconjugated steroids. Before aromatization, dehydroepiandrosterone must be converted to a $\Delta^{4}$-3-ketone- $\mathrm{C}_{19}$-steroid, namely androstenedione. Androstenedione is aromatized to estrone, which thence is converted to estradiol-17 $\beta$ through the action of $17 \beta$-HSD type 1 . Excessive conversion of androstenedione to testosterone in trophoblast could result in the virilization of female fetus as $\sim 15 \%$ of steroids synthesized in placenta enter the fetal circulation (see reference 1 ). The action of $17 \beta$-HSD type 2 in placenta may serve to maintain the 17-ketone of $C_{19}$-steroids to attenuate the formation of biologically potent androgen and to maintain the C-20-ketone of progesterone to ensure the bioaction of this progestation steroid hormone.

Using total RNA prepared from villous trophoblast isolated from human placenta and the $17 \beta$-HSD type 2 cDNA probe, we detected a major species of mRNA at $\sim 1.5 \mathrm{~kb}$. When the blot purchased from Clontech Laboratories, Inc. was probed with this same cDNA, a minor species at $\sim 1.3 \mathrm{~kb}$ was detected in addition to the major species at $\sim 1.5 \mathrm{~kb}$. Previously, when placental RNA was probed with the same cDNA probe, a signal : at $\sim 2.2 \mathrm{~kb}$ was detected in addition to the major mRNA species at $\sim 1.5 \mathrm{~kb}(11)$. This difference may be attributable to higher stringency of probing in this study. Indeed, it may be that alternative splicing gives rise to a longer mRNA as is the case for $17 \beta$-HSD type 1 . Two forms of $17 \beta$-HSD type $1 \mathrm{mRNAs}$ are present in most tissues: the major form in placenta is $1.3 \mathrm{~kb}$, and a $2.2-\mathrm{kb}$ mRNA with an extended 5 '-noncoding region is present in lower levels in placenta. In addition, it is possible that minor species of mRNA $(\sim 2.2$ and $1.3 \mathrm{~kb})$ are present in another extraembryonic, non-villous trophoblast tissue (e.g., umbilical cord, amnion, chorion laeve), which may have been present in the tissue/RNA preparation that was used in those studies.

Andersson and colleagues (11) could not detect 17 $\beta$-HSD type 2 mRNA in human prostate and the data obtained in this study also are indicative of very low levels of $17 \beta$-HSD type 2 mRNA in prostate. This is suggestive that an alternate form of $17 \beta$-HSD is expressed in prostate or else that testosterone inactivation in prostate is accomplished primarily by way of the $6 \alpha$ - or $7 \alpha / \beta$-hydroxylation of $5 \alpha$-androstan-3 $\beta, 17 \beta$-diol (11).

The anatomic distribution of $17 \beta$-HSD isozymes appears to be important in the synthesis of bioactive ( $17 \beta$-reduced) $\mathrm{C}_{19^{-}}$ and $\mathrm{C}_{18}$-steroids and thence in the inactivation (17-oxidation) of these steroids; $17 \beta$-HSD type 1 (placenta) catalyzes the biosynthesis of the potent estrogen, estradiol-17 $\beta ; 17 \beta$-HSD type 2 (endometrium) catalyzes the inactivation of estradiol to estrone; $17 \beta$-HSD type 1 provides for the synthesis of estradiol$17 \beta$ in placenta and $17 \beta$-HSD type 2 may ensure that there is little or no net synthesis of testosterone in this tissue. It now seems reasonable to suspect that yet other $17 \beta$-HSD isoenzymes will be discovered to account for testosterone synthesis in testis and to account for the conversion of plasma androstenedione to plasma testosterone and of plasma estrone to plasma estradiol-17 $\beta$ in extragonadal tissues.

\section{Acknowledgments}

The authors thank Valencia Hoffman for assistance in obtaining endometrial tissues, Jesse Smith, Patrick Keller, and Bobbie Mayhew for skilled technical assistance, and Kimberly McKinney for expert editorial assistance.

This investigation was supported, in part, by U. S. Public Health Service grant 5-P50-HD11149.

\section{References}

1. Cunningham, F. G., P. C. MacDonald, N. F. Gant, K. J. Leveno, and L. C. Gilstrap. 1993. Williams Obstetrics. Appleton \& Lange, Norwalk, CT.

2. Lloyd, C. W., J. Lobotsky, J. Weisz, D. T. Baird, J. A. McCracken, M. Pupkin, J. Zanartu, and J. Puga. 1971. Concentration of unconjugated estrogens, androgens and gestagens in ovarian and peripheral venous plasma of women: the normal menstrual cycle. J. Clin. Endocrinol. \& Metab. 32:155-166.

3. Weinstein, R. L., R. P. Kelch, M. R. Jenner, S. L. Kaplan, and M. M. Grumbach. 1974. Secretion of unconjugated androgens and estrogens by the normal and abnormal human testis before and after human chorionic gonadotropin. J. Clin. Invest. 53:1-6.

4. Baird, D. T. 1976. Content and secretion of steroids by the human ovary in vivo. In Proceedings of the Fifth International Congress of Endocrinology. vol I. V.H.T. James, editor. Excerpta Medica, Amsterdam. 330-336.

5. Chapdelaine, A., P. C. MacDonald, O. Gonzalez, E. Gurpide, R. L. VandeWiele, and S. Lieberman. 1965. Studies on the secretion and interconversion of androgens. IV. Quantitative results in a normal man whose gonadal and adrenal function were altered experimentally. J. Clin. Endocrinol. \& Metab. 25:15691579.

6. Bradshaw, K. D., J. I. Mason, C. R. Parker, Jr., P. C. MacDonald, L. Milewich, and B. R. Carr. 1994. Steroid secretory characteristics of a virilizing adrenal adenoma. J. Endocrinol. 140:297-307.

7. MacDonald, P. C., J. D. Madden, P. F. Brenner, J. D. Wilson, and P. K. Siiteri. 1979. Origin of estrogen in normal men and in women with testicular feminization. J. Clin. Endocrinol. \& Metab. 49:905-916.

8. MacDonald, P. C., A. Chapdelaine, O. Gonzalez, E. Gurpide, R. L. VandeWiele, and S. Lieberman. 1965. Studies on the secretion and interconversion of the androgens. III. Results obtained after the injection of several radioactive C19 steroids, singly or as mixtures. J. Clin. Endocrinol. \& Metab. 25:1557-1568.

9. Little, B., R. B. Billiar, S. S. Rahman, W. A. Johnson, Y. Takaoka, and R. J. White. 1975. In vivo aspects of progesterone distribution and metabolism. Am. J. Obstet. Gynecol. 123:527-534.

10. Labrie, F., J. Simard, V. Luu-The, G. Pelletier, A. Belanger, Y. Lachance, H.-F. Zhao, C. Labrie, N. Breton, Y. de Launoit, et al. 1992. Structure and tissue-specific expression of 3 beta-hydroxysteroid dehydrogenase/5-ene-4-ene isomerase genes in human and rat classical and peripheral steroidogenic tissues. J. Steroid Biochem. Mol. Biol. 41:421-435.

11. Wu, L., M. Einstein, W. M. Geissler, H. K. Chan, K. O. Elliston, and S. Andersson. 1993. Expression cloning and characterization of human $17 \beta-$ hydroxysteroid dehydrogenase type 2 , a microsomal enzyme possessing $20 \alpha$ hydroxysteroid dehydrogenase activity. J. Biol. Chem. 168:12964-12969.

12. Gast, M. J., H. F. Sims, G. L. Murdock, P. M. Gast, and A. W. Strauss. 1989. Isolation and sequencing of a complementary deoxyribonucleic acid clone encoding human placental $17 \beta$-estradiol dehydrogenase: identification of the putative cofactor binding site. Am. J. Obstet. Gynecol. 161:1726-1731.

13. Peltoketo, H., V. Isomaa, O. Maentausta, and R. Vihko. 1988. Complete amino acid sequence of human placental $17 \beta$-hydroxysteroid dehydrogenase deduced from cDNA. FEBS (Fed. Eur. Biochem. Soc.) Lett. 239:73-77.

14. Labrie, R., V. Luu-The, C. Labrie, D. Berube, J. Couet, H.-F. Zhao, R. Gagne, and J. Simard. 1989. Characterization of two mRNA species encoding human estradiol $17 \beta$-dehydrogenase and assignment of the gene to chromosome 17. J. Steroid Biochem. 34:1-6.

15. Blomquist, C. H., N. J. Lindemann, and E. Y. Hakanson. 1985. 17 $\beta$ Hydroxysteroid and $20 \alpha$-hydroxysteroid dehydrogenase activities of human placental microsomes: kinetic evidence for two enzymes differing in substrate specificity. Arch. Biochem. Biophys. 239:206-215.

16. Winqvist, R., H. Peltoketo, V. Isomaa, K. H. Grzeschik, A. Mannermaa, and $R$. Vihko. 1990. The gene for 17 beta-hydroxysteroid dehydrogenase maps to human chromosome 17, bands q12-q21, and shows an RFLP with ScaI. Hum. Genet. 85:473-476.

17. Tseng, L., and E. Gurpide. 1975. Induction of human endometrial estradiol dehydrogenase by progestins. Endocrinology. 97:825-833. 
18. Gurpide, E., L. Tseng, and S. B. Gusberg. 1977. Estrogen metabolism in normal and neoplastic endometrium. Am. J. Obstet. Gynecol. 129:809-816.

19. Tseng, L., and E. Gurpide. 1979. Stimulation of various $17 \beta$ - and $20 \alpha$ hydroxysteroid dehydrogenase activities by progestins in human endometrium. Endocrinology. 104:1745-1748.

20. Gurpide, E., S. B. Gusberg, and L. Tseng. 1976. Estradiol binding and metabolism in human endometrial hyperplasia and adenocarcinoma. J. Steroid Biochem. 7:891-896.

21. Holinka, C. F., and E. Gurpide. 1981. Hormone-related enzymatic activities in normal and cancer cells of human endometrium. J. Steroid Biochem. 15:183-192.

22. Tseng, L., S. B. Gusberg, and E. Gurpide. 1977. Estradiol receptor and $17 \beta$-dehydrogenase in normal and abnormal human endometrium. Ann. NY Acad. Sci. 286:190-198.

23. Satyaswaroop, P. G., D. J. Wartell, and R. Mortel. 1982. Distribution of progesterone receptor, estradiol dehydrogenase, and $20 \alpha$-dihydroprogesterone dehydrogenase activities in human endometrial glands and stroma: progestin induction of steroid dehydrogenase activities in vitro is restricted to the glandular epithelium. Endocrinology. 111:743-749.

24. Kitawaki, J., T. Tamamoto, and H. Okada. 1988. Induction of estradiol dehydrogenase activity in human uterine endometrium by synthetic steroids. $J$. Endocrinol. Invest. 11:351-354.

25. Byrjalsen, I., L. Thormann, B. Meinecke, B. J. Riis, and C. Christiansen. 1992. Sequential estrogen and progestogen therapy: assessment of progestational effects on the postmenopausal endometrium. Obstet. Gynecol. 79:523-528.

26. Scublinsky, A., C. Marin, and E. Gurpide. 1976. Localization of estradiol $17 \beta$-dehydrogenase in human endometrium. J. Steroid Biochem. 7:745-747.

27. Couture, P., C. Theriault, J. Simard, and F. Labrie. 1993. Androgen receptor-mediated stimulation of $17 \beta$-hydroxysteroid dehydrogenase activity by dihydrotestosterone and medroxyprogesterone acetate in ZR-75-1 human breast cancer cells. Endocrinology. 132:179-185.

28. Poutanen, M., V. Isomaa, K. Kainulainen, and R. Vihko. 1990. Progestin induction of $17 \beta$-hydroxysteroid dehydrogenase enzyme protein in the T-47D human breast cancer cell line. Int. J. Cancer. 46:897-901.

29. Casey, M. L., J. W. Smith, K. Nagai, L. B. Hersh, and P. C. MacDonald. 1991. Progesterone-regulated cyclic modulation of membrane metalloendopeptidase (enkephalinase) in human endometrium. J. Biol. Chem. 266:23041-23047.

30. Chirgwin, J. M., A. E. Przybyla, R. J. MacDonald, and W. J. Rutter. 1979. Isolation of biologically active ribonucleic acid from sources enriched in ribonuclease. Biochemistry. 18:5294-5299.

31. Sambrook, J., E. F. Fritsch, and T. Maniatis. 1989. Molecular Cloning A Laboratory Manual. Cold Spring Harbor Laboratory, Cold Spring Harbor, NY

32. Lichter, P., C. J. Tang, K. Call, G. Hermanson, G. A. Evans, D. Housman, and D. C. Ward. 1990. High-resolution mapping of human chromosome 11 by in situ hybridization with cosmid clones. Science (Wash. DC). 247:64-69.

33. Arici, A., J. R. Head, P. C. MacDonald, and M. L. Casey. 1993. Regulation of interleukin-8 gene expression in human endometrial cells in culture. Mol. Cell. Endocrinol. 94:195-204.

34. Wevrick, R., and H. F. Willard. 1989. Long-range organization of tandem arrays of alpha satellite DNA at the centromeres of human chromosomes: high- frequency array-length polymorphism and meiotic stability. Proc. Natl. Acad. Sci. USA. 86:9394-9398.

35. Thomas, C. M. G., and J. H. Veerkamp. 1976. The subcellular distribution of $17 \beta$-hydroxysteroid dehydrogenase in the human term placenta. Acta Endocrinol. 82:150-163.

36. Strickler, R. C., and B. Tobias. 1980. Estradiol $17 \beta$-dehydrogenase and $20 \alpha$-hydroxysteroid dehydrogenase from human placental cytosol: one enzyme with two activities? Steroids. 36:243-253.

37. Palmer, R., J. A. Blair, G. Eriksson, and E. Diczfalusy. 1966. Studies on the metabolism of C-21 steroids in the human foeto-placental unit. Acta Endocrinol. 53:407-419.

38. Gupride, E., and M. Welch. 1969. Dynamics of uptake of estrogens and androgens by human endometrium. J. Biol. Chem. 244:5159-5169.

39. Frost, P., E. C. Gomez, G. D. Weinstein, W. J. Lamas, and S. L. Hsia. 1969. Metabolism of progesterone-4- ${ }^{14} \mathrm{C}$ in vitro in human skin and vaginal mucosa. Biochemistry. 8:948-952.

40. Collins, J. A., and D. M. Jewkes. 1974. Progesterone metabolism by proliferative and secretory human endometrium. Am. J. Obstet. Gynecol. 118:179185.

41. Tremblay, Y., G. E. Ringler, Y. Morel, T. K. Mohandas, R. Labrie, J. F. Strauss III, and W. L. Miller. 1989. Regulation of the gene for estrogenic 17ketosteroid reductase lying on chromosome 17cen-q25. J. Biol. Chem. 264:20458-20462.

42. Marovitz, W., A. Loucopoulos, P. G. Satyaswaroop, E. Gurpide, R. Todd, and F. Naftolin. 1980. Apparent immunologic nonidentity of human placental and endometrial 17 $\beta$-estradiol dehydrogenase. Am. J. Obstet. Gynecol. 138:643-647.

43. Luu-The, V., C. Labrie, J. Simard, Y. Lachance, H.-F. Zhao, J. Couet, G. Leblanc, and F. Labrie. 1990. Structure of two in tandem human 17 $\beta$-dehydrogenase genes. Mol. Endocrinol. 4:268-275.

44. Martel, C., E. Rheaume, M. Takahashi, C. Trudel, J. Couet, V. Luu-The, J. Simard, and F. Labrie. 1992. Distribution of $17 \beta$-hydroxysteroid dehydrogenase gene expression and activity in rat and human tissues. J. Steroid Biochem. Mol. Biol. 41:597-603.

45. Tseng, L., and J. Mazella. 1980. Cyclic changes in estradiol metabolic enzymes in human endometrium during the menstrual cycle. In The Endometrium. F. A. Kimball, editor. S. P. Medical and Scientific Books, New York. 211-225.

46. Pack, B., R. Tovar, E. Booth, and S. Brooks. 1979. The cyclic relationship of estrogen sulfurylation to the nuclear receptor levels in human endometrial curettings. J. Clin. Endocrinol. \& Metab. 48:420-424.

47. Fleming, H., C. Namit, and E. Gurpide. 1980. Estrogen receptors in epithelial and stromal cells of human endometrium in culture. J. Steroid Biochem. 12:169-174

48. Pearlman, W. H. 1957. [ $\left.16-{ }^{3} \mathrm{H}\right]$ Progesterone metabolism in advanced pregnancy and in oophorectomized-hysterectomized women. Biochem. J. 67:1-

49. Siiteri, P. K., and P. C. MacDonald. 1963. The utilization of circulating dehydroisoandrosterone sulfate for estrogen synthesis during human pregnancy. Steroids. 2:713-730.

50. Siiteri, P. K., and P. C. MacDonald. 1966. Placental estrogen biosynthesis during human pregnancy. J. Clin. Endocrinol. \& Metab. 26:751-761. 